\title{
Filling the gap: a new ant-butterfly symbiosis in the forest canopy
}

\section{Gabriela Pérez-Lachaud}

El Colegio de la Frontera Sur

\section{Franklin H. Rocha}

Universidad Autónoma de Yucatán

\section{Carmen Pozo}

El Colegio de la Frontera Sur

\section{Lucas A. Kaminski}

Universidade Federal do Rio Grande do Sul

\section{Noemy Seraphim}

Instituto Federal de Educação, Ciência e Tecnologia de São Paulo

Jean-Paul Lachaud ( $\boldsymbol{\sim}$ jean-paul.lachaud@univ-tlse3.fr )

Université de Toulouse, CNRS, UPS

\section{Research Article}

Keywords: multitrophic interactions, myrmecophily, Pseudonymphidia agave, Neoponera villosa, brood predator, social parasites, Aechmea bracteata

Posted Date: July 16th, 2021

DOl: https://doi.org/10.21203/rs.3.rs-343521/v1

License: (c) (1) This work is licensed under a Creative Commons Attribution 4.0 International License.

Read Full License 


\section{Abstract}

Myrmecophilous butterflies can establish complex symbiotic relationships with ants. An elusive symbiotic caterpillar wandering among the brood of the aggressive ponerine ant, Neoponera villosa, was found inside the core of a nest built in the myrmecophytic bromeliad Aechmea bracteata. This is the first caterpillar found in symbiosis with a species of the subfamily Ponerinae. Tissue sample was barcoded, and an integrative approach was used to identify it as Pseudonymphidia agave, a poorly known Pachythonina member in the riodinid myrmecophilous tribe Nymphidiini. The caterpillar has a general tank-like body morphology, without projections or tubercles, and is covered dorsally by specialized flat setae that form an armor of small plates. Ant-organs potentially related to the caterpillar-ant signaling, such as perforated cupola organs and tentacle nectary organs, are present. These functional traits, together with the stable social integration, suggest that $\mathrm{P}$. agave is a specialized social parasite of $\mathrm{N}$. villosa. However, several knowledge gaps remain, notably the oviposition site, dependence on bromeliad association, steps to colony integration, and the larval diet through ontogeny. Carnivory has been reported in all known members of the Pachythonina subtribe (caterpillars prey on honeydew-producing hemipterans), and a shift to myrmecophagy inside the ant nests is a possible evolutionary step.

\section{Introduction}

Animals of several classes, especially arthropods, establish long term associations with ants and benefit from these facultative or obligate associations in several ways. These so called myrmecophiles (for a detailed definition, see ${ }^{1,2}$ ) circumvent the behavioral and chemical defenses of the ants and thrive in their homeostatic, stable nests or in their surrounding territories ${ }^{3,4}$. Living in concealed environments - the ant nests -, most specialized myrmecophiles are in general rare, restricted to specific habitats or even microhabitats. Moreover, they are unevenly distributed in time and space, thus presenting challenges for their study ${ }^{5}$.

Symbiotic associations between lepidopteran caterpillars and ants are diverse and widespread, spanning at least six lepidopteran superfamilies: Noctuoidea, Papilionoidea, Pyraloidea, Tineoidea, Gelechioidea, and Zygaenoidea ${ }^{6-8}$. These interactions range from commensalism or mutualism to social parasitism, and relationships may be facultative or obligate, occurring during only a portion or the whole life cycle of the myrmecophile ${ }^{9,10}$. These associations are noticeably prominent in two sister families of butterflies: Lycaenidae and Riodinidae (Papilionoidea) ${ }^{6}$. Myrmecophilous caterpillars of these families typically form symbioses with ants on host plants where the ants, and sometimes also the caterpillars, harvest liquid food from plants (extrafloral nectar) and exudates from hemipterans (aphids, treehoppers, scale insects and relatives) ${ }^{11-13}$. In trophobiotic interactions, the caterpillars secrete nutritional food rewards for ants and gain potential protection against predators and parasitoids ${ }^{11,14,15}$.

From this ancestral pattern (phytophagous caterpillars), several Lepidopteran lineages have evolved to exploit the ant-colony resources inside the ant nests, either as social parasites that elicit trophallaxis from 
workers, or as brood predators ${ }^{16-18}$. Although more than $99 \%$ of lepidopteran caterpillars are phytophagous, transition from feeding on plant parts to aphytophagy has occurred several times, with carnivorous caterpillars found scattered in the butterfly phylogeny ${ }^{19,20}$. Predation on ant brood has been documented in Lycaenidae, but not in the Riodinidae; however members of both families exhibit complex myrmecophily with the evolution of specific ant-organs and behavioral strategies to integrate and exploit the ant host colonies ${ }^{20}$ such as chemical, vibrational and tactile mimicry, ant-dependent oviposition, release of brood-carrying behavior, trophallaxis and others ${ }^{21-23}$. Those obligate social parasite species are completely dependent on the ants to fulfill their life cycle ${ }^{24}$.

Metalmark butterflies (Riodinidae) are classified into two subfamilies: the exclusively Neotropical Riodininae with ca. 1200 described species, and the Nemeobiinae which include both old-world and Neotropical groups ${ }^{25-27}$. Trophobiosis with ants in this family has evolved in parallel to the Lycaenidae ${ }^{12,20,28,29}$. According to Espeland et al. ${ }^{30}$, caterpillar-ant association has evolved once in the Lycaenidae and twice in the Riodinidae (in the tribes Eurybiini and Nymphidiini, both Riodininae).

Immatures of riodinid species for which life histories have been documented are defoliators, nectarivores, lichen feeders, detritivores, exploiters, and predators of hemipterans ${ }^{28,31}$. Approximately $20 \%$ of the known species of Riodinidae are involved in symbiotic associations with ants ${ }^{30}$. Several recent studies have played a role in unveiling the nature of riodinid-ant associations ${ }^{20,31-33}$, confirming the evolution of social parasitism in this family (kleptoparasitism via trophallaxis with ants within their nest) ${ }^{20}$. Myrmecophagy, though suspected in several instances, remains to be confirmed in the field ${ }^{34}$. Individuals of several ant subfamilies are frequently observed tending riodinids directly on host plants. Such associations are recurrent in members of the Myrmicinae, Formicinae, Dolichoderinae and Ectatomminae subfamilies, all of which are territorially dominant ants that harvest animal and plant secretions; however, they are very uncommon in the Ponerinae (see Supplementary Table S1). More intimate and stable relationships between riodinids and their host inside the ant nest, have also been described: some riodinid species rest and pupate in shelters constructed by ants, and others have been collected in ant nests of various formicine, myrmicine and dolichoderine species ${ }^{20,35-38}$; however, to the best of our knowledge, there is no record of a riodinid or a lycaenid as a guest within ponerine ant colonies.

Over the course of extensive fieldwork and sampling of colonies of the Neotropical ponerine ant, Neoponera villosa, in the southern region of the Yucatan Peninsula ${ }^{39,40}$, we recorded a single case of a butterfly caterpillar wandering among the ant brood. In this study we: (1) establish the identity of this symbiont through an integrative approach; (2) present some notes on both the natural history and behavior of the caterpillar; (3) describe and illustrate its external morphology; (4) discuss the putative functional significance of morphological traits that may have allowed this species to invade aggressive ant societies; and (5) compare them to other described social parasitic caterpillars.

\section{Results}


A myrmecophilous caterpillar (Fig. 1) was found among the ant brood in a N. villosa colony collected on June 10, 2017 at Ejido Blasillo, Campeche, Mexico (187'13.6056" N, 89¹9'47.791" W, $263 \mathrm{~m}$ asl). The caterpillar was isolated in a small petri dish and provided with a source of humidity. After several days, the larva appeared to be in a poor condition and was preserved in alcohol. Subsequent to the discovery of the myrmecophilous larva, collecting effort was renewed. In total, 19 nests were collected in the same locality ${ }^{40}$, but no other riodinid larva was found.

Caterpillar identification. The tree obtained placed our caterpillar barcode sequence within the Pachythonina subtribe (Fig. 2, Supplementary Table S2), sister to other previously sequenced Pseudonymphidia agave from Mexico (C. Pozo et al., unpubl. data). Indeed, the sequences of specimen MAL-05054 and of the collected caterpillar belong to the same barcode haplotype.

Since its original description as Lemonias agave Godman and Salvin, 1886, this species has not been revised. Presently, two subspecies of $P$. agave are recognized: nominal plus leucogonia (Stichel, 1911). Based on similarities in genital morphology, antennal length and wing pattern, Hall and Harvey ${ }^{42}$ temporarily placed agave and leucogonia in the genus Pseudonymphidia. This genus forms a monophyletic clade along with Pachythone, Roeberella and Pixus in the phylogenetic hypothesis of Seraphim et al. ${ }^{26}$, who erected the Pachythonina subtribe that included several genera placed as incertae sedis in previous revisions of the family. According to the phylogenetic tree obtained here (Fig. 2), the closest relative to the Pseudonymphidia genus recovered in this study is Archaeonympha drepana, a genus that was absent from the sampling used by Seraphim et al. ${ }^{26}$ but that should also be placed within the Pachythonina subtribe (N. Seraphim, unpubl. data).

Prevalence, natural history, and behavioral observations. Out of $82 \mathrm{~N}$. villosa colonies collected between January 2016 and April 2018 in several sites in the southern part of the Yucatan Peninsula, only one colony was infested with a riodinid larva, even though 19 of the colonies were from the same locality (Ejido Blasillo) and its surroundings. The caterpillar of $P$. agave was wandering among the host cocoons and larvae while workers were present, and no aggression was detected during a $3 \mathrm{~h}$ observation period. The host colony where the riodinid caterpillar was discovered nested in an A. bracteata bromeliad established at a height of $4 \mathrm{~m}$ on a Haematoxy/um campechianum tree (Fabaceae), situated in a patch of low deciduous forest. The colony was composed of 11 dealated queens, three gynes, 165 workers, 265 larvae, 173 cocoons, and plenty of eggs. Larvae and pupae (in cocoons) were not parasitized by endo- or ectoparasites. Apart from the riodinid larva, very few other myrmecophiles were hosted by the colony: only the cleptoparasitic mite Cosmolaelaps sp. (present on ant larvae, $\mathrm{N}=5$ ) and two species of staphylinid beetles (Myrmigaster sp. and Tyropsis sp., $\mathrm{N}=2$ and $\mathrm{N}=1$, respectively) were found in the nest chambers. Additionally, 17 adults of an unidentified species of Nitidulidae (Coleoptera), and 16 pseudoscorpions (Chelodamus mexicolens) were found in the nest refuse. 
Morphology of the Pseudonymphidia agave caterpillar. Head capsule width: $2.06 \mathrm{~mm}$, total length: $17.81 \mathrm{~mm}(\mathrm{~N}=1)$. Head brown; body pale brown with mottled dark spots corresponding to the color of the microscopic setae present in each region (Fig. 3A). Body onisciform without projections or tubercles, similar in size to the host cocoons (Figs. 1C, 3A). Head and appendages (legs and prolegs) concealed under the body, not visible dorsally (Figs. 3A, D, F). Anterior portion of the body wider than the posterior segments in dorsal view (Fig. 3A). Prothoracic shield bilobed (Fig. 3B). Tegument covered dorsally by arborescent flat setae that form an armor of small plates and perforated cupola organs (PCOs) (Figs. 3C, E, G). Downward pointing setae forming a fringe ventral-laterally (Fig. 3F), and elongated arborescent setae associated with the tentacle nectary organs (TNOs) on A8 (Figs. 3H-J). Prothoracic spiracle located ventrally (Fig 3D), abdominal spiracles aligned laterally, with exception of those on A2 and A8, which are located subdorsally; openings elevated with elliptical peritrema (Fig. 3I).

Distribution records for Pseudonymphidia agave adults.

Pseudonymphidia agave, the white-trailed metalmark or agave metalmark, is a rare species, with records only from a few localities. Based on museum specimens, $P$. agave has been recorded from as far north as San Luis Potosi in Mexico to Colombia in South America (Fig. 4). Specimens have been collected between 0 and $1600 \mathrm{~m}$ of altitude ${ }^{43}$. This species seems restricted to specific habitats in tropical forests; data of specimens correspond to adults collected in evergreen, semi-evergreen, deciduous, semideciduous, and cloud forest. Adults have been collected on rambutan flowers, Nephelium lappaceum (Sapindaceae), in a commercial plantation ${ }^{43}$, but caterpillar host plants are unknown and natural history information was not available prior to this study. Only 52 individuals from Mexico are hosted in collections around the world (see Supplementary Tables S3, S4). Regarding the museum specimens, flight activities are recorded almost the whole year, with a significant peak in June and a less important one in October (Supplementary Fig. S1), a pattern previously observed for the riodinid family and other small-sized butterflies whereby the largest populations have been recorded during the wettest season of the year ${ }^{44}$.

\section{Discussion}

The biodiversity in the canopy of tropical forests is a frontier of knowledge that can still reveal great surprises ${ }^{45}$. In these environments, ants are pervasive in terms of richness and abundance connecting species and trophic levels through antagonistic and mutualistic direct and indirect interactions (reviewed $\mathrm{in}^{46}$ ). Our endeavor to describe this specific type of biodiversity unveiled an unexpected symbiotic interaction between a butterfly caterpillar and an aggressive ant. Our report that Pseudonymphidia agave caterpillars are guests in the nests of Neoponera villosa is, to the best of our knowledge, the first case of a butterfly caterpillar in intimate symbiosis with a ponerine ant. Our finding is the first to provide information on the life cycle of a member of the genus Pseudonymphidia, of which the immature stages 
were previously unknown, and sheds light upon the possible evolutionary steps of social parasitism in riodinids.

In recent years, a substantial new information related to the immature stages of Riodinidae has been revealed ${ }^{20,47-52}$. Nevertheless, some lineages remain completely unknown, principally in Nymphidiini, suggesting that these taxa may exhibit specialized association with ants, including long periods inside the ant nests ${ }^{20,28,52}$. The discovery of the $P$. agave caterpillar reinforces this supposition. This species belongs to the recently erected subtribe Pachythonina (Nymphidiini), a clade diagnosed based on molecular characters ${ }^{26}$. This group comprises rare and restricted taxa associated with tropical forests and is the latest subtribe of Nymphidiini whose natural history information has been published ${ }^{31}$. Species in the Pachythonina for which some life history information is known, present armored carnivorous caterpillars specialized in preying on honeydew-producing hemipterans (e.g., Pachythone spp. $\left.{ }^{31,53}\right)$ and are thought to carry out ant-mediated oviposition on harmful ant-plant symbioses (i.e., use specific ants as oviposition cues; e.g., Minstrellus grandis ${ }^{33}$, or prey on ant brood (e.g., P. agave, this study). Although scattered, the available information indicates that the Pachythonina species demonstrate morphological and behavioral traits that allow coexistence with extremely aggressive ants, including unusual associations with pseudomyrmecine and ponerine ants (Supplementary Table S1).

Ponerine ants are a group of large aggressive ants with powerful stingers ${ }^{3}$. Most species are specialized or generalist predators, occupying a high trophic position ${ }^{54,55}$. The use of liquid foods on foliage, however, has been recorded for some species such as $N$. villosa which harvest liquid secretions from extrafloral nectaries, exudates from honeydew-producing hemipterans and secretions of some facultative myrmecophilous caterpillars ${ }^{56-58}$ (Supplementary Table S1). According to DeVries ${ }^{11}$ the evolution of symbiosis between caterpillars and ants is associated with genera of ants that harvest liquid food on vegetation. The aggressiveness and conspicuous appearance of $N$. villosa ants associated with liquid feeding on plants may have generated an ecological opportunity for the evolution of exploitation by preadapted caterpillars ${ }^{11,15,59,60}$. This hypothesis can be proved both in ecological time ${ }^{61}$ and evolutionary time if the specialization between $P$. agave caterpillars on $N$. villosa ants is confirmed.

Detailed behavioral interactions between the $P$. agave caterpillar and $N$. villosa ants could not be analyzed. However, numerous evidence suggest that the nature of the relationship between caterpillars of this riodinid and $N$. villosa is not facultative or simply casual: (i) the larva was found among the brood in the core of the ant nest, (ii) it has a general protective morphology, with the head retracted or maintained under the shield-like, thick cuticle of the body, (iii) it had a slow, gradual, slug-like movement behavior, and (iv) ants did not behave aggressively. These traits indicate a well-integrated myrmecophile species. Exchange of liquid food through regurgitation (stomodeal trophallaxis) is a highly evolved form of social food sharing, but it is infrequent in ponerine ants ${ }^{57,62}$. The first case of social parasitism in riodinids (exploitation of the colony resources through trophallaxis inside the ant host nest) has been recently reported in Aricoris arenarum (Riodininae: Lemoniadina) ${ }^{20}$, and a similar "cuckoo" life-style could be 
possible for the $P$. agave caterpillar. However, stomodeal trophallaxis is not known to occur in N. villosa ${ }^{57}$; instead, workers share liquid food by means of mandibular pseudo-trophallaxis: workers gather and transport liquid substances with surface tension to maintain a drop between the mandibles. In the nest, they offer the liquid to other workers who "spoon" some of the liquid ${ }^{57}$. Since the colony had no other source of food for the caterpillar but the ants themselves, and the general rigid morphology of the former likely prevents obtaining food by pseudo-trophallaxis, we further hypothesize that the caterpillar is most probably a brood predator (myrmecophagy), at least during the last instar. Furthermore, in adults of $P$. agave, the wings present a greasy appearance, a trait that has been considered as a potential sign of carnivory ${ }^{63,64}$. Carnivory in riodinid caterpillars has been documented in five lineages of Nymphidiini preying on ant-tended hemipterans on plants ${ }^{31}$; however, myrmecophagy has only been recorded under artificial conditions ${ }^{34,65}$.

The larva of $P$. agave differs from all other known riodinid caterpillars, though the general tank-like appearance is similar to other riodinids in the Lemoniadina (e.g., Menanderspp. ${ }^{28,66}$ ), and Pachythonina subtribes (e.g., Pachythone xanthe ${ }^{31}$ ). Although phytophagous, Menander caterpillars are covered with a prominent carapace that flares outward to the substrate and covers the body and legs; they are thus heavily armored and possess a complete set of ant-organs ${ }^{28,66}$. In $P$. xanthe caterpillars, the prothoracic shield divided vertically into two movable plates, the absence of vibratory papillae and a carapace that protects the head and appendages are undoubtedly the most remarkable traits ${ }^{31}$. Some of these larval characters such as the body shape, the morphology of the lateral fringe setae, and the positioning of the spiracles, are shared with $P$. agave, suggesting that they may be morphological synapomorphies for the subtribe. In fact, these morphological characters led us to classify the caterpillar as a potential Pachythonina before corroboration through molecular data.

Among myrmecophilous caterpillars, two strategies can be discerned: (i) free-living caterpillars that establish commensal or trophobiotic associations with ants on plants; and (ii) social parasite caterpillars that at some point of their development gain access to the ant nest ${ }^{20}$. This seems to be related to the ontogenetic moment when ant-organs and chemical compounds that trigger ant adoption are produced $^{67}$. The life cycle of $P$. agave appears to conform to the second strategy, but details of the access process to the ant colony are still unknown. In summary, our data strongly suggest that $P$. agave is an obligate symbiont in $N$. villosa nests and that the last larval instar is possibly myrmecophagous. Whether females lay eggs directly on the external leaves or inflorescences of the bromeliad is not known but seems possible. As suggested for other specific lycaenid species associated with ants ${ }^{68}$, the scarcity of this butterfly might be explained by its highly specialized life history, making the butterfly distribution dependent on the $N$. villosa-bromeliad association. Finding answers to the questions raised in this study can only be possible with more field effort and new data on natural history.

\section{Material And Methods}


The ant-plant symbiotic system. Neoponera villosa is widely distributed from Mexico to Argentina ${ }^{69}$. This is the largest of the Mexican ant species; workers measure 1.2 to $1.3 \mathrm{~cm}^{70}$ and are provided with a powerful and painful sting. They are generalist predators and forage mainly in the canopy collecting at liquid carbohydrate food sources ${ }^{56-58}$. This species nests opportunistically in pre-existing cavities in live and dead trees ${ }^{71,72}$; in the southern part of the Yucatan Peninsula, Mexico, it preferentially uses the myrmecophytic tank-bromeliad Aechmea bracteata as a nest site ${ }^{39-41,71}$. In the A. bracteata microcosmos, a diverse array of specialized and facultative myrmecophiles, mostly antagonists, establish complex trophic interactions with $N$. villosa ${ }^{40}$. Up to date, various invertebrates have been recorded in direct association with the brood of this species and can be considered as true myrmecophiles ${ }^{40}$. Three of them are brood parasitoids: an unidentified species of Kapala Cameron (Hymenoptera: Eucharitidae) ${ }^{40}$, an unidentified species of Blanchardiscus de Santis (Hymenoptera: Encyrtidae) ${ }^{73}$, and the hoverfly Hypselosyrphus trigonus Hull (Diptera: Syrphidae) ${ }^{73,74}$. Two species (the pseudoscorpion, Chelodamus mexicolens, and an unidentified tenebrionid beetle possibly of the Alleculinae subfamily) are brood predators, while two mites (an unidentified oplitid species of the genus Oplitis and an unidentified galumnid species) are phoretic on the host larvae and a third unidentified mite species (of the genus Cosmolaelaps) is cleptoparasite on the larvae; finally two other species (a staphylinid beetle of the genus Myrmigaster and a diapriid wasp of the genus Trichopria) have unclear relationships but have been found wandering on the cocoons with their antennae in direct contact with the host cocoon surface ${ }^{40}$.

Sampling. Ant colonies $(\mathrm{N}=82)$ nesting in the core of the tank-bromeliad A. bracteata (Figs. 1A, B) were collected between January 2016 and April 2018 in several sites in the southern part of the Yucatan Peninsula as part of a larger project ${ }^{39,40}$. Briefly, A. bracteata bromeliads were examined for the presence of $N$. villosa and a ramet of the epiphyte, housing the ants' colony, was cut off from the supporting branch and dismantled leaf-by-leaf; ants, their brood, and any invertebrate myrmecophile found in the nest were collected and preserved in $96^{\circ}$ alcohol. Ants and their associated fauna were collected under Mexican government research permit granted to GP-L (SEMARNAT, DGVS, License number FAUT-0277).

DNA barcoding. DNA extraction was performed on two of the thoracic legs of the larva using a standard glass fiber method ${ }^{75}$. Polymerase chain reactions were performed to amplify the mitochondrial cytochrome c oxidase subunit I (COI) gene, using the primers LepF1 and LepR1 developed for Lepidoptera by Hebert et al. ${ }^{76}$, and PCR protocols as in Montes-Ortiz and Elías-Gutiérrez ${ }^{77}$. PCR products were visualized on a $2 \%$ agarose gel (E-Gel 96 Invitrogen), and were sequenced bidirectionally on an $A B I$ 3730XL automated sequencer using LepF1 and LepR1 primers at the Instituto de Biología at the Universidad Nacional Autónoma de México. The sequence was edited using CodonCode v. 3.0.1 (CodonCode Corporation, Dedham, MA, USA) and uploaded to Barcode of Life Database (BOLD, 
boldsystems.org) and to GenBank (www.ncbi.nlm.nih.gov; accession number MW627452). We added this larval sequence to a database of published COI barcodes and unpublished sequences (C. Pozo et al., unpubl. data; N. Seraphim, unpubl. data). Sequences were then combined with a larger matrix of Riodinidae species for a total of 269 specimens comprising all previously sequenced Riodinidae $25,26,30$ including eight nuclear genes as well as the mitochondrial barcode region as described in Seraphim et al. ${ }^{26}$ : AK, CAD, GAPDH, Ef1a, IDH, MDH, RpS5, wgl and COI (Supplementary Table S2). This expanded matrix was used to obtain a maximum likelihood tree using IQtree software version 1.6.12 ${ }^{78}$, with Curetis barsinae (Lycaenidae: Curetinae) as an outgroup. The model of nucleotide substitution was estimated using the model selection implemented in IQtree ${ }^{79}$. Support was estimated using 10000 rapid boostraps $^{80}$ and SH-aLRT test ${ }^{81}$. The resulting tree was collapsed for clarity.

Morphology. The caterpillar was examined using a Nikon dissecting stereomicroscope (8-64X) and a JEOL-JSM6010 scanning electron microscope (SEM) equipped with a freezing plate; it was examined under low vacuum at $20 \mathrm{Kv}$ and $-31^{\circ} \mathrm{C}$ to preserve the integrity of the specimen. Approximate measurements and ratios of measurements were obtained using SEM images. Photos of the larva were taken with a Nikon 850D equipped with a Rodenstok Rodagon $2.850 \mathrm{~mm}$ lens adapted to a Beseler bellows. A metric scale was included in the photos for calibration. Photos were stacked with HeliconFocus 6.2.2 and processed in Photoshop ${ }^{\circledR}$. Voucher specimens (the riodinid larva and $N$. villosa ants) were deposited at the Formicidae and Lepidoptera Collections of El Colegio de la Frontera Sur at Chetumal, Quintana Roo, México (ECO-CH-F and ECO-CH-L, respectively). The terminology for the description follows Stehr ${ }^{82}$ for general morphology of the larva and DeVries ${ }^{83}$ for ant-organs.

\section{Flight period and distribution map.}

To provide an actualized distribution map and data on adult flight phenology, we compiled distribution data from the literature and from records in the MARIPOSA Data Base at the Museo de Zoología "Alfonso L. Herrera," Facultad de Ciencias, UNAM, Mexico. This database synthesizes information from Mexican specimens housed in natural history collections around the world. In addition, we used information from the Data Base of the Lepidoptera Collection at ECOSUR and data bases available on internet or published literature for specimens of countries other than Mexico: https://www.gbif.org/ for Honduras, Nicaragua, Trinidad \& Tobago; https://www.butterfliesofamerica.com/ for Costa Rica; Godman and Salvin ${ }^{84}$ and D’Abrera $^{85}$ for Panamá; Lamas ${ }^{86}$ for Colombia.

\section{References}

1. Kronauer, D. J. C. \& Pierce, N. E. Myrmecophiles. Curr. Biol. 21, R208-209 (2011). 
2. Parker, J. Myrmecophily in beetles (Coleoptera): evolutionary patterns and biological mechanisms. Myrmecol. News 22, 65-108 (2016).

3. Hölldobler, B. \& Wilson, E. O. The ants. Harvard University Press, Cambridge, MA (1990).

4. Hughes, D. P., Pierce, N. E. \& Boomsma, J. J. Social insect symbionts: evolution in homeostatic fortresses. Trends Ecol. Evol. 23, 672-677 (2008).

5. Lachaud, J.-P., Lenoir, A. \& Witte, V. Ants and their parasites. Psyche 2012, Article ID 342157; $10.1155 / 2012 / 342157$ (2012).

6. Hinton, H. E. Myrmecophilous Lycaenidae and other Lepidoptera- a summary. Proc. Trans. South Lond. Entomol. Nat. Hist. Soc. 1949-1950, 111-175 (1951).

7. Pierce, N. E. Predatory and parasitic Lepidoptera: carnivores living on plants. J. Lepid. Soc. 49, 412453 (1995).

8. Dejean, A. et al. Ant-lepidopteran associations along African forest edges. Sci. Nat. 104, 7 (2017).

9. Fiedler, K. Systematic, evolutionary, and ecological implications of myrmecophily within the Lycaenidae (Insecta: Lepidoptera: Papilionoidea). Bonn. Zool. Monogr. 31, 1-210 (1991).

10. Pierce, N. E. et al. The ecology and evolution of ant association in the Lycaenidae (Lepidoptera). Annu. Rev. Entomol. 47, 733-771 (2002).

11. DeVries, P. J. Mutualism between Thisbe irenea butterflies and ants, and the role of ant ecology in the evolution of larval-ant associations. Biol. J. Linn. Soc. 43, 179-195 (1991).

12. DeVries, P. J. Evolutionary and ecological patterns in myrmecophilous riodinid butterflies. In: Huxley, C. R. \& Cutler, D. F. (eds.) Ant-Plant Interactions. Oxford University Press, Oxford, pp 143-156 (1991).

13. DeVries, P. J. Butterflies. Encyclopedia of Biodiversity 1, 559-573 (2001).

14. Pierce, N. E. \& Mead, P. S. Parasitoids as selective agents in the symbiosis between lycaenid butterfly larvae and ants. Science 211, 1185-1187 (1981).

15. Kaminski, L. A., Freitas, A. V. L. \& Oliveira, P. S. Interaction between mutualisms: ant-tended butterflies exploit enemy-free space provided by ant-treehopper associations. Am. Nat. 176, 322-334 (2010).

16. Balduf, W. V. The rise of entomophagy among Lepidoptera. Am. Nat. 72, 358-379 (1938).

17. Cottrell, C. B. Aphytophagy in butterflies: its relationship to myrmecophily. Zool. J. Linn. Soc. 79, 157 (1984).

18. Fiedler, K. Lycaenid-ant interactions of the Maculinea type: tracing their historical roots in a comparative framework. J. Insect Conserv. 2, 3-14, (1998).

19. Kaliszewska, Z. A et al. When caterpillars attack: Biogeography and life history evolution of the Miletinae (Lepidoptera: Lycaenidae). Evolution 69, 571-588 (2015).

20. Kaminski, L. A., Volkmann, L., Callaghan, C. J., DeVries, P. J. \& Vila, R. The first known riodinid 'cuckoo' butterfly reveals deep-time convergence and parallelism in ant social parasites. Zool. J. Linn. Soc. (2021) https://doi.org/10.1093/zoolinnean/zlaa150.

21. Sala, M., Casacci, L. P., Balleto, E., Bonelli, S. \& Barbero, F. Variation in butterfly larval acoustics as a strategy to infiltrate and exploit host ant colony resources. PLoS ONE 9, e94341 (2014). 
22. Schönrogge, K., Barbero, F., Casacci, L. P., Settele, J., Thomas, J. A. Acoustic communication within ant societies and its mimicry by mutualistic and socially parasitic myrmecophiles. Anim. Behav. 134, 249-256 (2017).

23. Casacci, L. P., Bonelli, S., Balleto, E. \& Barbero, F. Multimodal signaling in myrmecophilous butterflies. Front. Ecol. Evol. 7, 454 (2019).

24. Thomas, J. A., Elmes, G. W. \& Wardlaw, J. C. Polymorphic growth in larvae of the butterfly Maculinea rebeli, a social parasite of Myrmica ant colonies. Proc. R. Soc. Lond. B 265, 1895-1901 (1998).

25. Espeland, M. et al. Ancient Neotropical origin and recent recolonisation: Phylogeny, biogeography and diversification of the Riodinidae (Lepidoptera: Papilionoidea). Mol. Phylogenet. Evol. 93, 296306 (2015).

26. Seraphim, N. et al. Molecular phylogeny and higher systematics of the metalmark butterflies (Lepidoptera: Riodinidae). Syst. Entomol. 43, 407-425 (2018).

27. Seraphim, N. Riodinidae Species Checklist: a preliminary species checklist for the Riodinidae (2019). Available at: https://www2.ib.unicamp.br/labor/site/?page_id=805.

28. DeVries PJ. The butterflies of Costa Rica and their natural history. Vol II: Riodinidae. Princeton University Press, Princeton (1997).

29. Campbell, D. L., Brower, A. V. Z. \& Pierce, N. E. Molecular evolution of the wingless gene and its implications for the phylogenetic placement of the butterfly family Riodinidae (Lepidoptera: Papilionoidea). Mol. Biol. Evol. 17, 684-696 (2000).

30. Espeland, M. et al. A comprehensive and dated phylogenomic analysis of butterflies. Curr. Biol. 28, 770-778 (2018).

31. Mota, L. L., Kaminski, L. A. \& Freitas, A. V. L. The tortoise caterpillar: carnivory and armoured larval morphology of the metalmark butterfly Pachythone xanthe (Lepidoptera: Riodinidae). J. Nat. Hist. 54, 309-319 (2020).

32. Nielsen, G. J. \& Kaminski, L. A. Immature stages of the Rubiaceae-feeding metalmark butterflies (Lepidoptera: Riodinidae), and a new function for the tentacle nectary organs. Zootaxa 4524, 1-32 (2018).

33. Kaminski, L. A., Carneiro, E., Dolibaina, D. R., Casagrande, M. M. \& Mielke, O. H. H. Oviposition of Minstrellus grandis (Lepidoptera: Riodinidae) in a harmful ant-plant symbiosis. Acta Amazon. 50, 256-259 (2020).

34. Kaminski, L. A. \& Lima, L. D. Larval omnivory in the myrmecophilous butterfly Setabis lagus lagus (Riodinidae: Nymphidiini). J. Lepid. Soc. 73, 276-279 (2019).

35. Bruch, C. Orugas mirmecofilas de Hameris epulus signatus - Stich. Rev. Soc. Entomol. Argent. 1, 2-9 (1926).

36. Bourquin, F. Notas sobre la metamorfosis de Hamearis susanae Orfila, 1953, con oruga mirmicófila (Lep. Riodin.). Rev. Soc. Entomol. Argent. 16, 83-87 (1953). 
37. Ross, G. N. Life-history studies on Mexican butterflies. IV. The ecology and ethology of Anatole rossi, a myrmecophilous metalmark (Lepidoptera: Riodinidae). Ann. Entomol. Soc. Am. 59, 985-1004 (1966).

38. Kaminski, L. A. \& Carvalho-Filho, F. S. Life history of Aricoris propitia (Lepidoptera: Riodinidae)-A myrmecophilous butterfly obligately associated with fire ants. Psyche 2012, Article ID 126876; 10.1155/2012/126876 (2012).

39. Rocha, F. H., Lachaud, J.-P., Hénaut, Y., Pozo, C. \& Pérez-Lachaud, G. Nest site selection during colony relocation in Yucatan Peninsula populations of the ponerine ant Neoponera villosa (Hymenoptera: Formicidae). Insects 11, 200; 10.3390/insects11030200 (2020).

40. Rocha, F. H., Lachaud, J.-P. \& Pérez-Lachaud, G. Myrmecophilous organisms associated with colonies of the ponerine ant Neoponera villosa (Hymenoptera: Formicidae) nesting in Aechmea bracteata bromeliads: a biodiversity hotspot. Myrmecol. News 30, 73-92 (2020).

41. Dejean, A. \& Olmsted, I. Ecological studies on Aechmea bracteata (Swartz) (Bromeliaceae). J. Nat. Hist. 31, 1313-1334 (1997).

42. Hall, J. P. W. \& Harvey, D. J. A phylogenetic analysis of the Neotropical riodinid butterfly genera Juditha, Lemonias, Thisbe and Uraneis, with a revision of Juditha (Lepidoptera: Riodinidae: Nymphidiini). Syst. Entomol. 26, 453-490 (2001).

43. Arellano-Covarrubias, A., Llorente-Bousquets, J. \& Luis-Martínez, A. Distribución y fenología de la familia Riodinidae (Lepidoptera: Papilionoidea) en el bosque tropical subcaducifolio de Oaxaca, México. Rev. Biol. Trop. 66, 503-558 (2018).

44. Pozo, C. et al. Seasonality and phenology of the butterflies (Lepidoptera: Papilionoidea and Hesperioidea) of Mexico's Calakmul Region. Fla. Entomol. 91, 407-422 (2008).

45. Erwin, T. L. Tropical forest canopies: the last biotic frontier. Bull. Entomol. Soc. Am. 29, 14-19 (1983).

46. Rico-Gray, V. \& Oliveira, P. S. The ecology and evolution of ant-plant interactions. The University of Chicago Press, Chicago (2007).

47. DeVries, P. J., Cabral, B. C. \& Penz, C. M. The early stages of Apodemia paucipuncta (Riodinidae): myrmecophily, a new caterpillar ant-organ and consequences for classification. Milw. Public Mus. Contrib. Biol. Geol. 102, 1-13 (2004).

48. Kaminski, L. A., Mota, L. L., Freitas, A. V. L. \& Moreira, G. R. P. Two ways to be a myrmecophilous butterfly: natural history and comparative immature-stage morphology of two species of Theope (Lepidoptera: Riodinidae). Biol. J. Linn. Soc. 108, 844-870 (2013).

49. Kaminski, L. A., Mota, L. L. \& Freitas, A. V. L. Larval cryptic coloration and mistletoe use in the metalmark butterfly Dachetola azora (Lepidoptera: Riodinidae). Entomol. Am. 120, 18-23 (2014).

50. Torres, P. J. \& Pomerantz, A. F. Butterfly kleptoparasitism and first account of immature stages, myrmecophily, and bamboo host plant of the metalmark Adelotypa annulifera (Riodinidae). J. Lepid. Soc. 70, 130-138 (2016).

51. Gallard, J.-Y. Les Riodinidae de Guyane. Pensoft, Sofia (2017). 
52. Hall, J. P. W. A monograph of the Nymphidiina (Lepidoptera: Riodinidae: Nymphidiini): Phylogeny, taxonomy, biology, and biogeography. The Entomological Society of Washington, Washington (2018).

53. Moraga Medina, R. 2014. Pachythone gigas (Riodinidae). Área de Conservación Guanacaste (2014). https://www.acguanacaste.ac.cr/paginas-de-especies/insectos/111-160riodinidae/581-ipachythone-gigas-i-riodinidae

54. Davidson, D. W., Cook, S. C., Snelling, R. R. \& Chua, T. H. Explaining the abundance of ants in lowland tropical rainforest canopies. Science 300, 969-972 (2003).

55. Schmidt, C. A. \& Shattuck, S. O. The higher classification of the ant subfamily Ponerinae (Hymenoptera: Formicidae), with a review of ponerine ecology and behavior. Zootaxa 3817, 1-242 (2014).

56. Lachaud, J.-P., Fresneau, D. \& García-Pérez, J. Étude des stratégies d'approvisionnement chez 3 espèces de fourmis ponérines (Hymenoptera: Formicidae). Folia Entomol. Mex. 61, 159-177 (1984).

57. Hölldobler, B. Liquid food transmission and antennation signals in ponerine ants. Isr. J. Entomol. 19, 89-99 (1985).

58. Dejean, A. \& Corbara, B. Predatory behavior of a Neotropical arboricolous ant: Pachycondyla villosa (Formicidae: Ponerinae). Sociobiology 17, 271-286 (1990).

59. Atsatt, P. R. Lycaenid butterflies and ants: selection for enemy-free space. Am. Nat. 118, 638-654 (1981).

60. Dáttilo, W. et al. Trait-mediated indirect interactions of ant shape on the attack of caterpillars and fruits. Biol. Lett. 12, 20160401 (2016).

61. Orivel, J. \& Dejean, A. Myrmecophily in Hesperiidae. The case of Vettius tertianus in ant gardens. C.R. Acad. Sci. Paris 323, 705-715 (2000).

62. Meurville, M.-P. \& LeBoeuf, A. C. Trophallaxis: the functions and evolution of social fluid exchange in ant colonies (Hymenoptera: Formicidae). Myrmecol. News 31, 1-30 (2021).

63. Hall, J. P. W. \& Harvey, D. J. Basal subtribes of the Nymphidiini (Lepidoptera: Riodinidae): phylogeny and myrmecophily. Cladistics 18, 539-569 (2002).

64. Hall, J. P. W. Phylogenetic revision of the new Neotropical riodinid genus Minstrellus (Lepidoptera: Riodinidae). Ann. Entomol. Soc. Am. 100, 773-786 (2007).

65. Ballmer, G. R. \& Wright, D. M. Notes on the immature stages of Setabis sp., a myrmecophagous riodinid butterfly (Lepidoptera: Riodinidae). J. Res. Lepid. 47, 11-15 (2014).

66. Callaghan, C. J. Studies on Restinga butterflies: I. Life cycle and immature biology of Menander felsina (Riodinidae), a myrmecophilous metalmark. J. Lepid. Soc. 31, 173-182 (1977).

67. Hojo, M. K, Yamaguchi, S., Akino, T. \& Yamaoka, R. Adoption of lycaenid Niphanda fusca (Lepidoptera: Lycaenidae) caterpillars by the host ant Camponotus japonicus (Hymenoptera: Formicidae). Entomol. Sci. 17, 59-65 (2014). 
68. Maschwitz, U., Nässig, W. A., Dumpert, K. \& Fiedler, K. Larval carnivory and myrmecoxeny, and imaginal myrmecophily in miletine lycaenids (Lepidoptera, Lycaenidae) on the Malay Peninsula. Tyô to Ga 39, 167-181 (1988).

69. Mackay, W. P. \& Mackay, E. E. The systematics and biology of the New World ants of the genus Pachycondyla (Hymenoptera: Formicidae). The Edwin Mellen Press, New York, NY (2010).

70. Wheeler, W. M. The ants of Texas, New Mexico and Arizona. Part I. Bull. Am. Mus. Nat. Hist. 24, 399485 (1908).

71. Dejean, A., Olmsted, I. \& Snelling, R. R. Tree-epiphyte-ant relationships in the low inundated forest of Sian Ka'an biosphere reserve, Quintana Roo, Mexico. Biotropica 27, 57-70 (1995).

72. Fernandes, I. O., De Oliveira, M. L. \& Delabie, J. H. C. Notes on the biology of Brazilian ant populations of the Pachycondyla foetida species complex (Formicidae: Ponerinae). Sociobiology 60, 380-386 (2013).

73. Pérez-Lachaud, G. \& Lachaud, J.-P. Hidden biodiversity in entomological collections: The overlooked co-occurrence of dipteran and hymenopteran ant parasitoids in stored biological material. PLOS ONE 12 , e0184614 (2017).

74. Pérez-Lachaud, G., Jervis, M. A., Reemer, M. \& Lachaud, J.-P. An unusual, but not unexpected, evolutionary step taken by syrphid flies: the first record of true primary parasitoidism of ants by Microdontinae. Biol. J. Linn. Soc. 111, 462-472 (2014).

75. Ivanova, N. V., DeWaard, J. R. \& Hebert, P. D. N. An inexpensive, automation-friendly protocol for recovering high-quality DNA. Mol. Ecol. Notes 6, 998-1002 (2006).

76. Hebert, P. D. N., Penton, E. H., Burns, J. M., Janzen, D. H. \& Hallwachs, W. Ten species in one: DNA barcoding reveals cryptic species in the neotropical skipper butterfly Astraptes fulgerator. Proc. Nat. Acad. Sci. USA 101, 14812-14817 (2004).

77. Montes-Ortiz, L. \& Elías-Gutiérrez, M. Faunistic survey of the zooplankton community in an oligotrophic sinkhole, Cenote Azul (Quintana Roo, Mexico), using different sampling methods, and documented with DNA barcodes. J. Limnol. 77, 428-440 (2018).

78. Nguyen, L.-T., Schmidt, H. A., von Haeseler, A. \& Minh, B. Q. IQ-TREE: a fast and effective stochastic algorithm for estimating maximum-likelihood phylogenies. Mol. Biol. Evol. 32, 268-274 (2015).

79. Kalyaanamoorthy, S., Minh, B. Q., Wong, T. K. F., von Haeseler, A. \& Jermiin, L. S. ModelFinder: fast model selection for accurate phylogenetic estimates. Nat. Methods 14, 587- 589 (2017).

80. Hoang, D. T., Chernomor, O., von Haeseler, A., Minh, B. Q. \& Vinh, L. S. UFBoot2: Improving the ultrafast bootstrap approximation. Mol. Biol. Evol. 35, 518- 522 (2018).

81. Guindon S. et al. New algorithms and methods to estimate maximum-likelihood phylogenies: assessing the performance of PhyML 3.0. Syst. Biol. 59, 307-321 (2010).

82. Stehr, F. W. Order Lepidoptera. In: Stehr, F. W. (ed.) Immature insects. Vol. 1. Kendall-Hunt Publishing Company, Dubuque (1987). 
83. DeVries, P. J. The larval ant-organs of Thisbe irenea (Lepidoptera: Riodinidae) and their effects upon attending ants. Zool. J. Linn. Soc. 94, 379-393 (1988).

84. Godman, F. D. \& Salvin, O. Biologia Centrali-Americana. Insecta. Lepidoptera-Rhopalocera 1: 462, pl. 47, fig. 7-8. Published for the editors by R.H. Porter, London (1886).

85. D'Abrera, B. Butterflies of the Neotropical Region. Part VI (Riodinidae). Hill House, Victoria, Australia (1994).

86. Lamas, G. Hesperioidea - Papilionoidea. In: Heppner, J. B. (ed.) Atlas of Neotropical Lepidoptera. Checklist: Part 4A. Association for Tropical Lepidoptera, Gainesville, Florida (2004).

\section{Declarations}

\section{Acknowledgements}

We are grateful to Humberto Bahena Basave (ECOSUR) for help with the photos; to Alma Estrella GarcíaMorales, from the Laboratory for DNA barcoding at ECOSUR-Chetumal that forms part of the Mexican Barcode of Life (MEXBOL) network, for DNA extraction; to Blanca R. Prado-Cuellar for sample processing, pictures of the riodinid adults (MAL-05053 and MAL-05054) and design of Figure 4; to Sandra López and León Ibarra for help with field work. SEM photographs were taken with a JEOL 6010 microscope at ECOSUR Chetumal by Manuel Elías-Gutiérrez to whom we are deeply indebted. FHRV was supported by a CONACyT grant during his PhD (Grant number 269825). LAK was supported by Coordenação de Aperfeiçoamento de Pessoal de Nível Superior (PNPD-CAPES), and by the National Geographic Society (\#WW-224R-17).

\section{Figures}



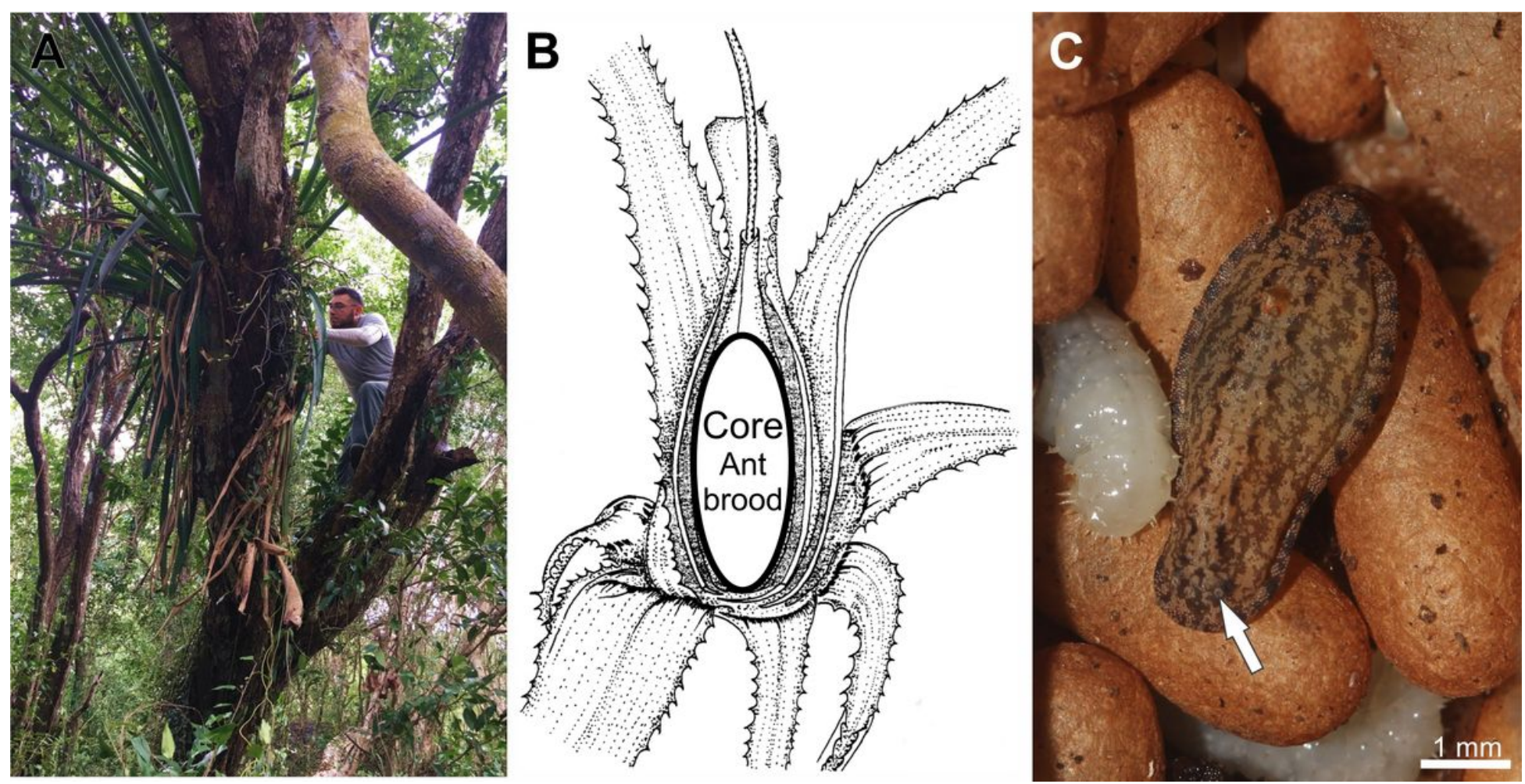

\section{Figure 1}

Pseudonymphidia agave caterpillar and the ant-plant system. (A) habitat of Aechmea bracteata (nest collector: F.H. Rocha). (B) ant nesting site in the bromeliad (modified from41). (C) Mature larva of P. agave among the ant brood; the arrow indicates the opening of a tentacle nectary organ on the A8 abdominal segment. Photos: (A) G. Pérez-Lachaud; (C) F. H. Rocha. 


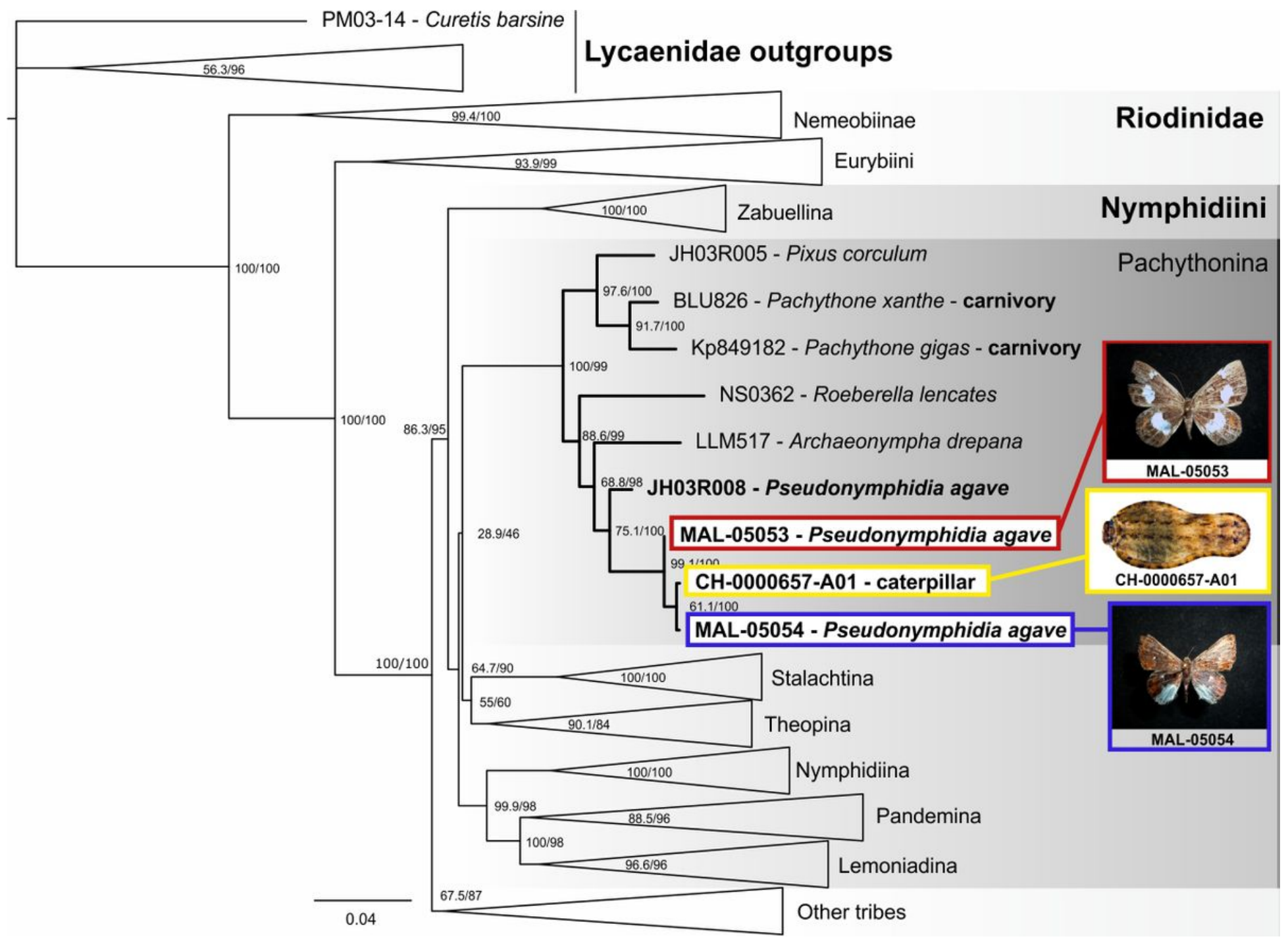

\section{Figure 2}

Maximum likelihood tree of the Riodinidae, used to identify the collected larva, showing its systematic position within the subtribe Pachytonina. The remaining clades within the Riodinidae have been collapsed for clarity. Pseudonymphidia agave sequences are illustrated with photos of the adults: MAL05053, MAL-05054 (Photos: B. R. Prado-Cuellar) and the caterpillar (Photo: H. Bahena Basave). 

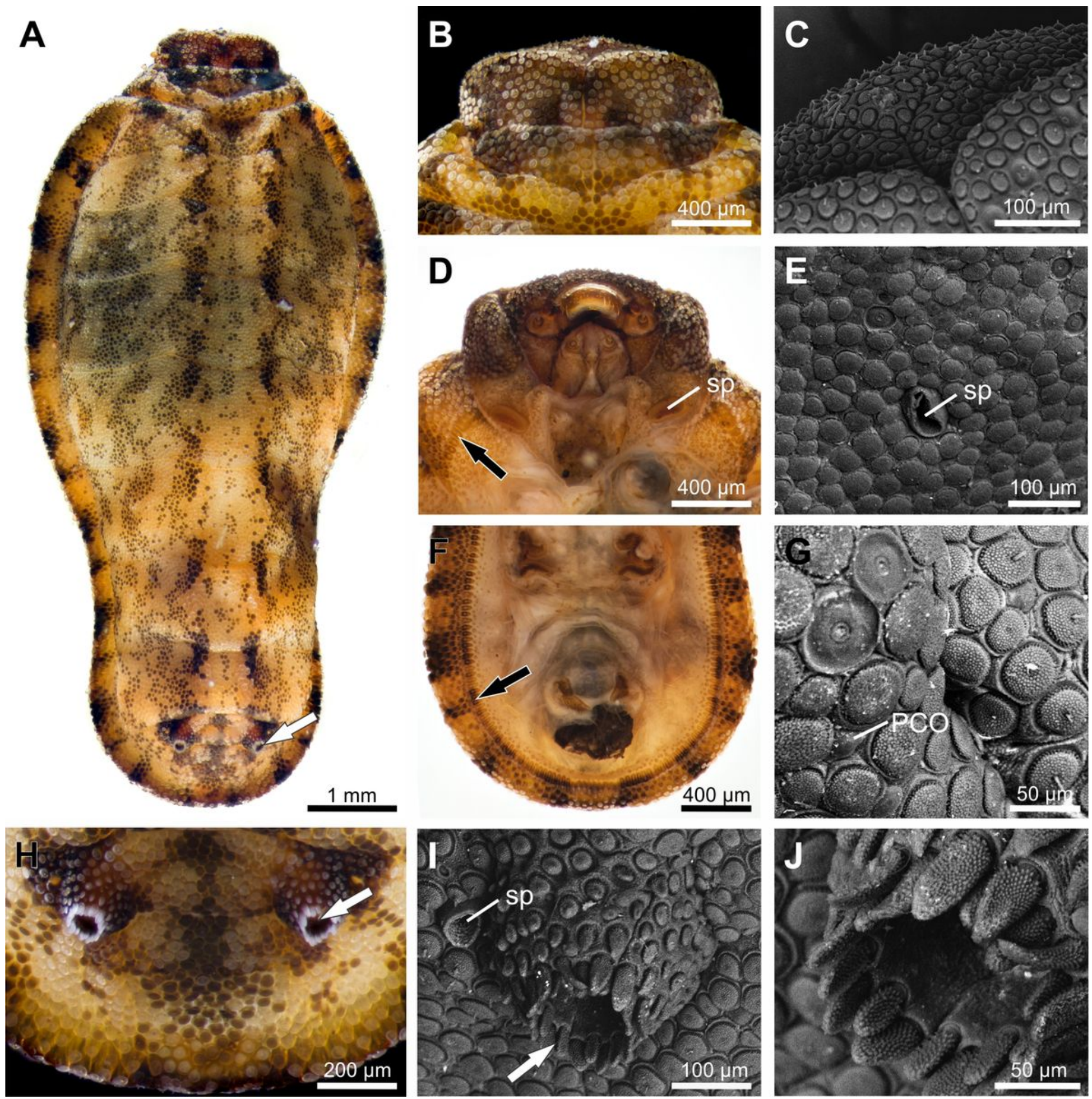

\section{Figure 3}

Morphology of the Pseudonymphidia agave caterpillar and details in scanning electron microscopy (SEM). (A) dorsal view, the arrow indicates the openings of the tentacle nectary organs (TNOs) on the A8 abdominal segment. (B) bilobed prothoracic shield in dorsal view. (C) SEM of the bilobed prothoracic shield. (D) ventral view of the head and thoracic segments, showing the prothoracic spiracle (sp) and fringe of setae (black arrow). (E) SEM of the spiracle (sp) on the A3 abdominal segment. (F) ventral view of the last abdominal segments; note lateral fringe of setae (black arrow). (G) SEM of the tegument 
covered dorsally by arborescent flat setae and perforated cupola organs (PCO). (H) opening of TNO (arrow); I) and J) SEMs of the opening of TNO (arrow), showing spiracle (sp) and elongated arborescent setae. Photos: (A, B, D, F, H) H. Bahena Basave; (C, E, G, I, J) M. Elias-Gutiérrez.

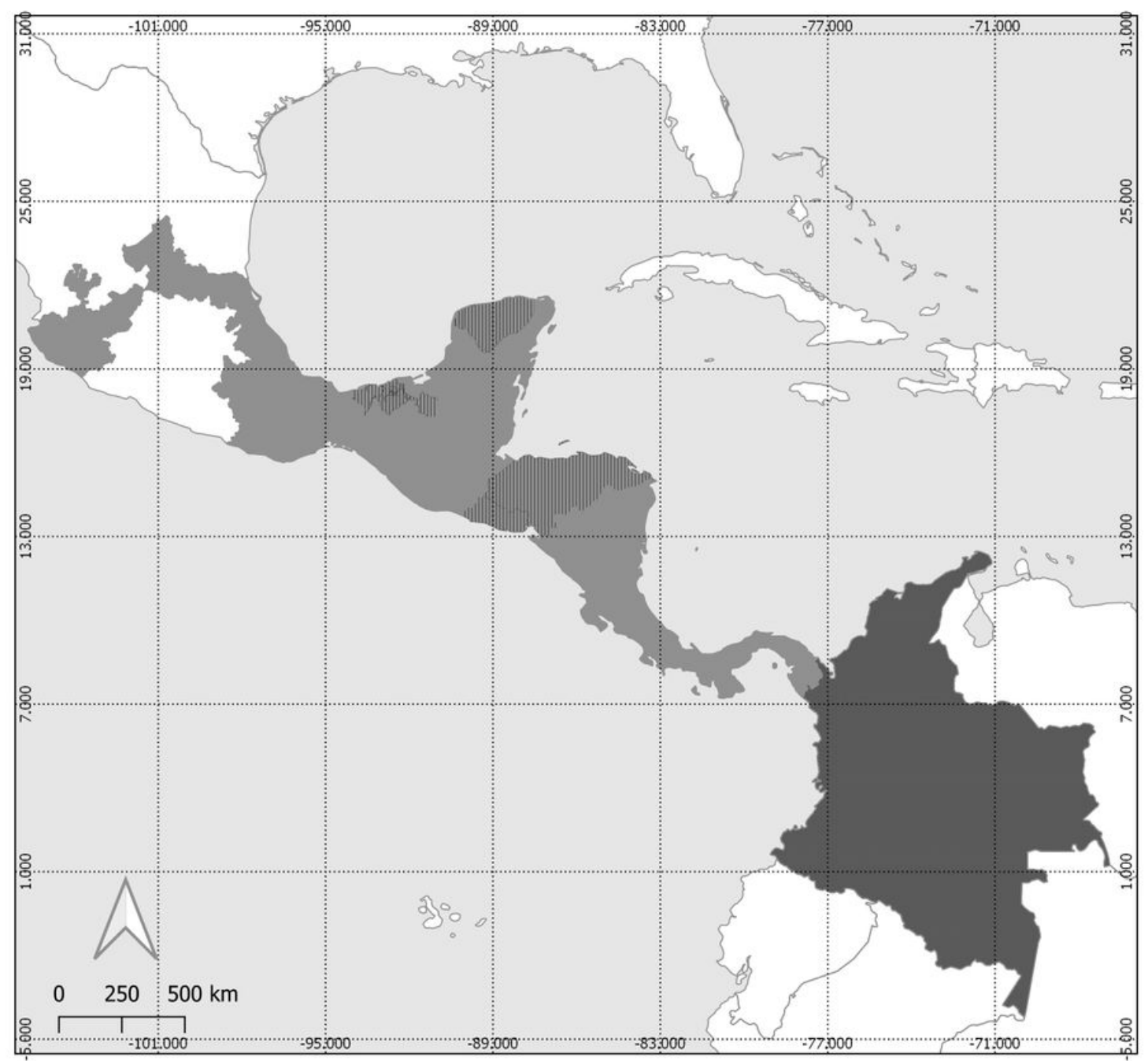

$P$. agave distribution

$P$. agave agave

$P$. agave leucogonia

Potential distribution

\section{Figure 4}

Known distribution of Pseudonymphidia agave. Records were compiled from published literature, Museum databases and internet catalogs (see Material and Methods for more details).

\section{Supplementary Files}

This is a list of supplementary files associated with this preprint. Click to download.

- PerezLachaudetalSupplementaryInformation.pdf 